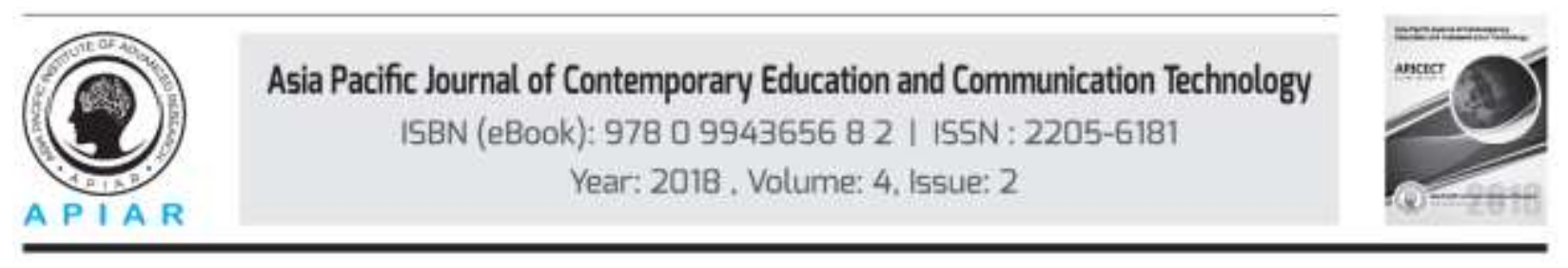

\title{
ICT INTERVENTION DURING TEACHER TRAINING IN THE INDIAN EDUCATION SYSTEM
}

\author{
Dr. Chasul \\ Era University, Lukhnow, India \\ Corresponding Email: pchasul@gmail.com
}

\begin{abstract}
The present study is the result of an attempt made for delving deeper into the inclusion of ICT i.e. Information and Communication Technologies into the teacher education in India. The policy documents emphasize the role of technology in education at all levels, but it was found during the $\mathrm{PhD}$ study of the researcher that the practical implementation of the technology part is missing at almost all levels in the public institutions. The teachers are not up-to-dated with the ICTs evolving in the market. In order to gain an insight of the incorporation of ICT in teacher education in urban settings the present study was conducted. The sample population was chosen from the teacher training institutes of (Bachelor of Education) B.ed from established public universities of New Delhi. The respondents were contacted through emails and after getting confirmation, they were approached for semi-structured interviews. The results of the study strongly recommend inclusion of ICT as a core subject during the B.ed course of teachers.
\end{abstract}

Keywords: Bachelor of Education, Core Subject, Information and Communication

Technology, Public Institutions, Semi-structured Interviews.

\section{Introduction}

The education system of a country is the backbone for the development of the nation. The education sector also helps to accelerate the process of Economic growth and raise the living standards of people (Guru, 2016). The key stakeholders of the education system of any country are the teachers/practitioners, the researchers, and the policy makers. The network of these three pillars is responsible for deciding the foundation for the learners. It is quite essential that the problems faced by the practitioner teachers should be reached to the researchers of the education domain. The researchers should work upon these problems and find appropriate solutions. The research results should reach the practitioners from time to time. One should not wait till the end of the complete process. These problems and solutions should be reached to the policy makers, and they must synthesize new policies based upon the results and suggestions of these two bodies (OECD, 2007).

ICT can play a crucial role in bridging the gap mentioned above. ICT can play its role at various levels. At the first stage, it should be used by the teachers to prepare their teaching material and likewise to use ICT to assist their pedagogy inside the classroom. Dissemination process accelerates the most when mediated by a human. ICT is important for creating new ideas and to disseminate the existing ideas. Therefore, the combination of these two (teacher and ICT) teacher is the best way to create new ideas, information and to disseminate the existing knowledge; moreover it opens new avenues for networking between stakeholders. Therefore, the 
next step where ICT is needed to be involved is at the stakeholders' level for networking is a very important component of knowledge sharing and knowledge management.

But there are several issues related with the implementation of it. The training received by teachers and doctors both influence their profession very much (Hargreaves, 2001). The mere availability of ICT is not sufficient for its usage; training is required, which is not very common in practice. The results of the PhD research of the researcher proved that there is a lack of training for ICT usage and practice. Although the scenario has improved in some private institutions, but more need of training in the public universities is required in order to prepare efficient users of technology, not only the students, but the teachers.

Digital natives easily use ICT in their daily lives as compared to the digital immigrants (Prensky, 2001). Teachers come under the category of digital immigrants; therefore they need more external motivation in order to include ICT tools in their pedagogy. The pre-service education acts as the foundation of their prospective carriers. It is very important to get them exposed with ICT during this crucial phase. The results of the study suggest that during their pre-service education, the Student Teachers are not getting enough exposure with ICTs in India. These student teachers are not trained in a way that they would be able to incorporate ICT smoothly when they would actually start to teach. Moreover, at some places, ICT is a component of the curriculum, but the first hand practice is missing. The art of cooking, art of playing, art of teaching, or art of using a technology cannot be mastered by merely reading about it, practice is required. The same rule is applied in using ICT for teaching, or for networking, knowledgesharing or any similar task.

In the present study, an attempt has been made to find out whether the ICT intervention is there at the universities located in the national capital. The chances of advancement are always higher in remote located areas and rural settings. The respondents reported that there is very less focus on the integration of ICT in the pedagogy of teachers at their institutions. The discussion part would elaborate on the results obtained.

\section{Research Problem}

The researcher has identified the gap during her $\mathrm{PhD}$ study. As reported by the in-service teachers that they did not receive any proper training during their pre-service education. Fewer opportunities are provided during their in-service training also. The researcher decided to explore the actual scenario during pre-service training. The research is conducted to explore that either the opportunities are available to use and access ICT during the pre-service training or not.

\section{Review of Literature}

The teacher plays a prominent role in deciding what the learners would learn and how would they learn. It is quite essential to prepare teachers with confident usage of ICT so that they can use it efficiently inside the classroom and motivate the students to use it outside the classroom as well. According to Brand (1998), "if students are going to be prepared for a technological society, they must be taught by confident and competent teachers. This can only be done by adequately training and the development of teachers." (Goktas \& Yildirim, 2008 p. 13).

The importance of ICT is evident; there was a major project about ICT integration in initial teacher training project in OECD countries. There is an emphasis on ICT integration in the teacher education. The government emphasizes ICT integration for the economic development of a nation (Brun, and Hinostroza, 2014). The similar attitude is required in developing nations such as India. The respondents of the present study strongly wanted to include ICT into their course, however, lack of hardware support is the main barrier. (Goktas, Yildirim, \&Yildirim, 
2009). There are certain similar issues attached with the integration of ICT intervention in the education sector. Adequate training is one of the major problems faced by the teachers today.

Inclusion of ICT in the teaching and learning process is not integrated in the pedagogy; the survey conducted by the researcher proves it with the results. The benefits of ICT are known to the people of academia, the awareness is there, but effective integration is missing. Three factors- content knowledge, pedagogical knowledge, and technological knowledge; if one from these are missing then the chances of the success rate would be low (Mou, 2016). The authors suggest the integration of ICT at 3 levels- the curriculum level, the topic level, and the lesson level (Wang \& Woo, 2007). The use of technology at different levels would help to explore its features in multiple ways. Similar other models can be synthesized according to needs and context in order to make the usage and adoption more fruitful.

It is a general tendency to use those gadgets first which are simple and easy to handle (Kalonde and Mousa, 2015). Generally, digital immigrants start with the simpler versions of technology first and later they tend to explore the complex forms (Prensky, 1990).

The literature suggests that ICT intervention has gained adequate attention in the developing nations. The scenario in the Indian context is entirely different. In some private institutions, the ICT intervention can be located, but in the public institutions there is a strong need to include it in the pedagogy. Review of literature suggests that the availability of the infrastructure, hardware, and assistance ship are some crucial elements responsible for the usage and diffusion of technology in any context. The need of the hour is efficient teachers, who can handle technology effectively and fruitfully. They must have the quality of flexibility, adaptability and to connect easily (Hargreaves, 1999). The teacher education is the foundational phase which prepares teachers for their future carriers; therefore opportunities should be given at this stage so that they can imbibe it completely into their pedagogy skills.

\section{Methodology}

Primary data was gathered using the survey method. Semi-structured interviews were conducted with the student teachers. The questions used for the interview was based on the constructs adopted from the Unified model of Acceptance and Use of Technology (UTAUT) model by Venkatesh et.al. Convenient sampling method was used to choose the universities. Another major reason for choosing the universities of New Delhi was that majority of the renowned and old universities are located in New Delhi. Snow-ball sampling was used for selecting the respondents for the interviews. The interviews were recorded using an Android smart phone and the transcription was done using word document. The total number of universities selected was 03 , and the total number of interviews considered for the final inclusion in the study was 30 .

Secondary data was collected by reading the description of the courses offered by the universities on their websites. Documents were gathered from the websites of University Grants Commission (UGC) and the Ministry of Human Resource Development (MHRD) the two central bodies responsible for the Higher Education system in India.

\section{Data Analysis and Discussion}

The opinions of the student teachers were compiled into a word document after active listening of the interview conversations. Respondents from all the chosen universities, strongly wanted technology oriented pedagogy. As reported by the primary and secondary data, there were a total of 8 subjects in the first year of their study in the Bachelor of Education course. The second year of the B.ed course is devoted to the practice of teaching in going to the schools for teaching practice. Among these 8 core courses, 2 are the teaching specific subjects and the remaining 6 are theory papers of theory. There is no technology related course as a core course. Educational 
Technology is an elective course which can be taken by few students. There are always limited options to choose an elective course.

The focus is on the core courses during the first year of the study, whereas the time devoted for the elective courses is almost negligible. The respondents suggested that the time devoted to other core subjects can be deducted by borrowing few minutes from all of them and devoted for ICT practice. Although some student teachers reported that they sometimes get chances of peer learning. The students with a background of exposure with handling technology help those who do not have much exposure with it. "There should be an ICT component in all the semesters so that no body lags behind" a respondent said.

The student teachers of a university reported that a workshop of 5 days is conducted once in a year for ICT exposure. But they mentioned that 5 days in 365 days does not fulfill our basic requirements. Student teachers of another university suggested that first-hand knowledge of some software would be given to them in near future as promised by their teachers. But none of the university had classrooms with smart board technologies, which is a basic requirement for incorporating technology. The traditional blackboard methods are used in their classrooms.

"The country is moving towards digitalization, so we cannot cut off ourselves from technology. Sometimes, there are movie screenings, some documentaries are also shown, but the time duration is less. It should be increased" responded a student teacher. At times they were mentioning about the digital India campaign. They mentioned about the period of demonetization. "If proper foundation was given to take off the plan, basic guidance about internet banking or similar other information of using apps to go digital, would have helped the common people to deal with things smoothly" said a respondent. Similarly, the basic information and practice is an essential component to make the teachers future ready.

"We have two huge fully equipped labs where we can sit and access technology, but there is no one to assist us by explaining the methods to use the computers kept over there" said one respondent. "We have come from a background where there were only blackboards in the classrooms" said another. An educational institution is the major for knowledge acquisition; therefore, complete care should be taken of providing ample opportunities for ICT learning; by either including it strictly into the pedagogy or by implementing the already made policies.

"In order to understand the nuances and start using ICT perfectly, one needs to absorb it" said one respondent enthusiastically. "There is a need of creating such an environment where there is a perfect atmosphere to sink deeper into technology and overcome the anxiety factor". It was evident from the interview sessions that this young generation of student teachers is keen on exploring ICT in their present state and upcoming future carriers. On one hand, they were focusing on the role of a teacher also. Without an efficient teacher, it is not possible to deliver technological content, therefore the role of a teacher to master the technological part is very essential.

\section{Conclusion}

ICT has proved its significance in almost all the spheres of life. The concepts of innovative learning environments, flipped classroom, e-learning, blended learning and similar concepts are accepted and admired across the globe today. The prominent features of ICTs and allied technologies are widely accepted. It breaks the monotony and makes things easier to comprehend in an interesting manner. The prominent feature of ICT is the ability to connect; it connects the old media with new media, it connects the learners to the teachers even in a situation of physical distance. ICT can also help to bring the stakeholders of education together, the three major pillars, the practitioners, the researchers and the policy makers. The inclusion of ICT in all the stages of teaching and learning is very crucial. The teachers who are responsible for the future of the students should be given excellent environments to unfold the layers of ICT 
and create miracles. There is a focus on ICT integration in the education domain, especially in the teacher education courses. Unfortunately there are various universities in India where there is no strict incorporation of the ICT. Few universities were chosen for the study, but all of them were reputed universities. The government should take some strict initiatives in this line. Proper steps should be taken not in the documents of education policies on the surface level, but at the implementation level also. 


\section{References}

i. Brun, M., \& Hinostroza, E., 2014. Learning to become a teacher in the 21st century: ICT integration in Initial Teacher Education in Chile. Journal of Educational Technology \& Society, 17(3), p. 222.

ii. Chai, C., Koh, L., Tsai, C., \& Tan, W., 2011. Modeling primary school pre-service teachers' Technological Pedagogical Content Knowledge (TPACK) for meaningful learning with information and communication technology (ICT). Computers \& Education, 57(1), pp. 1184-1193.

iii. Hargreaves, D., 1999. The knowledge-creating school. British journal of educational studies, 47(2), pp. 122-144.

iv. Goktas, Y., Yildirim, Z., \&Yildirim, S., 2008. A review of ICT related courses in pre-service teacher education programs. Asia Pacific Education Review, 9(2), pp. 168-179.

v. Goktas, Y., Yildirim, S., \&Yildirim, Z., 2009. Main barriers and possible enablers of ICTs integration into pre-service teacher education programs. Journal of Educational Technology \& Society, 12(1), p. 193.

vi. Jung, I., 2005. ICT-pedagogy integration in teacher training: Application cases worldwide. Educational Technology \& Society, 8(2), pp. 94-101.

vii. $\quad$ Kalonde, G., \&Mousa, R., 2015. Technologies Teacher Educators Model to Pre-Service Teachers in the Methods Courses. In: Kalonde ed. Society for Information Technology \& Teacher Education International Conference. Sl.: Association for the Advancement of Computing in Education (AACE), pp. 3295-3295)

viii. Mou, S., 2016. Possibilities and Challenges of ICT Integration in the Bangladesh Education System. Educational Technology, pp. 50-53.

ix. $\quad$ Prensky, M., 2001. Digital natives, digital immigrants part 1. On the horizon, 9(5), pp. 1-6.

x. $\quad$ Tondeur, J., van Braak, J., Sang, G., Voogt, J., Fisser, P., \& Ottenbreit-Leftwich, A., 2012. Preparing pre-service teachers to integrate technology in education: A synthesis of qualitative evidence. Computers \& Education, 59(1), pp. 134-144.

xi. Wang, Q., \& Woo, H. L.,2007. Systematic planning for ICT integration in topic learning. Educational technology \& society, 10(1), pp. 148-156. 